\title{
Short titles of Old English texts: addenda and corrigenda
}

\author{
BRUCE MITCHELL, CHRISTOPHER BALL \\ and ANGUS CAMERON
}

The compilers of the list of 'Short Titles of Old English Texts', ASE 4 (1975), 207-21, have received some valuable criticisms and suggestions for its improvement and have now had four years' experience of using the list. As a result some additions and corrections are necessary. We are grateful to the editors of Anglo-Saxon England, and in particular to Professor Peter Clemoes, for the opportunity of presenting them here.

A few general points must be made before the alterations proposed for specific short titles are discussed. No criticisms of the principles on which the list was based have been received and the compilers have found no reason for altering them. A specific merit of the system is its flexibility. It provides for the supplementation of a short title by the addition of (an obvious abbreviation for) the name of an editor of the text and/or of a detailed reference to an edition (see $A S E$ 4, 208-9). Users of the short titles will find that they can sometimes save their reader the trouble of referring to Cameron's 'List of Old English Texts' by using one or both of these devices. These have been strikingly exploited by F. Wenisch (Anglia 96 (1978), 8-18); some of his suggestions have been incorporated in our list. If desired, a short title can similarly be supplemented by adding the name of the text, e.g. \& $L S 32$ (Edmund), $L S_{3}$ (Chad) and LS Io (Gutblac). This meets, in part at least, an objection made by T. F. Hoad (RES 28 (1977), 194).

The compilers stated, 'When there is a conflict between the Cameron number of an item and that in the specified edition, the former will prevail' (ASE 4, 208). To this sentence should be added the words 'except where otherwise specified, namely in EHom, EELS, VercHom and WHom.' ECHom will be referred to by volume number, page and line in Thorpe's edition until the editions by P. A. M. Clemoes ( $\approx C H o m ~ r)$ and M. R. Godden ( ECHOm II) have been published.

In issuing this revision the compilers wish to draw special attention to $A S E$ 4, 209, n.I - 'It is desirable that future editors give marginal references to the edition which they (hope to) supersede' - and would now replace 'desirable' by 'essential'. 


\section{Bruce Mitchell, Christopher Ball, Angus Cameron}

We are grateful for the criticisms of individual short titles which we have received. Some of the offenders have been altered. Others have not. There are two reasons for this apparent obstinacy. The first - and more important is that alterations would sometimes have involved departure from the principles on which the list was based. The second is that, when considering short titles like Capt and Fort, which a reviewer included among 'the least likeable or guessable', we found it hard to think of something more likeable or guessable and so left ill alone. But the proviso 'that no decree nor statute which the king established may be changed' is not applicable here and we will welcome suggestions for the improvement of any short title, provided they comply with our basic principles.

PROPOSED ALTERATIONS AND ADDITIONS

Verse texts

\section{Corrigenda}

for Exo read Ex

for $W$ ald read $W$ ald $A$ Waldere I (vi. 4-s)

for Winfrid read ProvW

WaldB Waldere II (vi. s-6)

\section{Prose texts}

Addenda

\begin{tabular}{|c|c|c|c|}
\hline $\begin{array}{l}\text { Short title } \\
\text { ECHomP }\end{array}$ & $\begin{array}{l}\text { Reference number } \\
\text { Вг.т, I.2 }\end{array}$ & $\begin{array}{l}\text { Identifying title } \\
\text { Pericopes not printed } \\
\text { in full in Thorpe's edi- } \\
\text { tion }\end{array}$ & $\begin{array}{l}\text { Reference to edition by } \\
\text { Napier (as for gospels) }\end{array}$ \\
\hline EGenPref & B8.I.I & $\begin{array}{l}\text { Elfric's Preface to } \\
\text { Genesis }\end{array}$ & $\begin{array}{l}\text { Crawford, pp. } 7^{6-80} \\
\text { (by line) }\end{array}$ \\
\hline EJudgE $p$ & B8.1.6 & $\begin{array}{l}\text { Ælffric's Epilogue to } \\
\text { Judges }\end{array}$ & $\begin{array}{l}\text { Crawford, pp. 4I4-17 } \\
\text { (by line) }\end{array}$ \\
\hline HomNap & - & $\begin{array}{l}\text { Portions of homilies, } \\
\text { printed by Napier, } \\
\text { but not covered by an } \\
\text { existing abbreviation, } \\
\text { e.g.pp. } 98 \text {, line s-1or, } \\
\text { lines }\end{array}$ & $\begin{array}{l}\text { Napier (by page and } \\
\text { line) }\end{array}$ \\
\hline
\end{tabular}

Corrigenda

for $\operatorname{Pr} B l$ read Probib

for VSal read VSal I Assmann, pp. I81-92

VSal 2 Assmann, pp. 193-4 
Short titles of Old English texts: addenda and corrigenda

Continuous interlinear and occasional glosses

Addenda

\begin{tabular}{|c|c|c|c|}
\hline Short title & Reference number & Identifying title & Reference to edition by \\
\hline$A P G l$ & - & Anderson Pontifical & $\begin{array}{l}\text { Gough, Anglia } 92 \\
\text { (1974), 287-90; see } \\
\text { also Anglia } 95 \text { (1977), } \\
\text { 1 20-1 }\end{array}$ \\
\hline TatGl & - & Ars Tatuini & $\begin{array}{l}\text { Law, } A S E 6 \text { (1977), } \\
77-89\end{array}$ \\
\hline
\end{tabular}

\section{Corrigenda}

for DProv read DurProv

for RitGl read DurRitGl

as the identifying title of $P_{s} \mathrm{Ca}$ read Canticles accompanying the psalter

Inscriptions

\section{Corrigendum}

for NRune read Inscr 